\title{
Analysis of Natural Antioxidants by Capillary Electromigration Methods.
}

Miguel Herrero, Elena Ibáñez, Alejandro Cifuentes*

Institute of Industrial Fermentations, CSIC, Juan de la Cierva 3, 28006 Madrid, Spain

Correspondence: Alejandro Cifuentes; acifuentes@ifi.csic.es; Institute of Industrial Fermentations (CSIC), Juan de la Cierva 3, 28006 Madrid, Spain. Tel: 34-91-5622900. Fax: 34-91-5644853.

Keywords: capillary electrophoresis, food analysis, antioxidants, nutraceuticals, functional foods, polyphenols

Abbreviations: $\beta$-CD, $\beta$-ciclodextrin; CE, capillary electrophoresis; CEC, capillary electrochromatography; CGE, capillary gel electrophoresis; CIEF, capillary isoelectro focusing; CITP, capillary isotachophoresis; CyDTA, trans-1,2-diamino-cyclohexanetetra acetic acid monohydrate; CZE, capillary zone electrophoresis; ESI, electrospray interface; FI-CE, flow injection capillary electrophoresis; FOSHU, food for specific health use; LIF, laser induced fluorescence; LOD, limit of detection; MEKC, micellar electrokinetic chromatography; MES, morpholine-ethanesulphonic acid; MS, mass spectrometry; NACE, non aqueous capillary electrophoresis; ODS, octadecylsilica; PLE, pressurized liquid extraction; SBE- $\beta C D$, sulfobutyl ether- $\beta$-ciclodextrin; SDS, sodium dodecyl sulfate; TEA-TFB, tetraethylammonium tetrafluoroborate; TOF, time of flight. 


\section{SUMMARY}

In this work, an exhaustive revision on capillary electromigration methods applied to analyze natural antioxidants is presented together with some discussion on their use as functional foods. This review provides an updated and exhaustive overview regarding the separation and identification by capillary electrophoresis of natural compounds with antioxidant activity found in natural matrices and/or foods. The revised compounds are catechins, isoflavones, anthocyanins, phenolic acids, vitamins, as well as other less common natural substances that have shown antioxidant activity. 


\section{CONTENTS}

1. Introduction.

2. Phenolic compounds.

2.1. Flavonoid compounds.

2.1.1. Catechins.

2.1.2. Isoflavones.

2.1.3. Anthocyanins.

2.1.4. Other flavonoids.

2.2. Phenolic acids and other phenolic compounds.

2.2.1. Resveratrol.

2.2.2. Other phenolic compounds.

3. Vitamins.

4. Other antioxidants.

5. Conclusions and future outlooks. 


\section{INTRODUCTION}

In recent years, there has been a growing interest in functional foods, that is, foods that can provide not only the basic nutritional and energetic requirements but also an additional physiological benefit [1]. The name, functional food, was used for the first time in Japan on the 80's and it was related to processed food that contained ingredients that conferred benefits to some physiological functions. They were known as FOSHU (Foods for Specified Health Use). Nowadays a functional food can be defined as the food that produces a beneficial effect in one or more physiological functions, increases the welfare and/or decrease the risk of suffer a particular disease. Besides, the effect provided by a functional food should be effective at the usual eating habits. Usually, the functionality of a food is related to some of the ingredients that contains and, at present, these ingredients are preferred by consumers to have a natural origin (i.e., non synthetics) being commonly extracted from plants, food by-products and other natural sources [2].

Among the functional ingredients, the group most widely studied is the family of antioxidants. Traditionally, this kind of compounds has played an important role in Food Science and Technology because of their usefulness as a preservation method against oxidative degradation of foods. Usually, food production processes can generate important losses of endogenous antioxidants that limit their own protection against lipid oxidation. Thus, even when the oxidation can be delayed with the use of different kind of packaging (vacuum packaging, inert gas atmosphere packaging, packaging in materials that exclude light and air), antioxidant compounds are pointed out as essential in the current food manufacturing industry [3].

A classification of the antioxidants can be established based on their mechanism of action as follows [4]: primary antioxidants, that terminate the oxidation chain reaction by donating hydrogen or electrons to free radicals; synergistic, that are classified as oxygen scavengers and chelators; and secondary antioxidants, that prevent the oxidation by decomposing the lipid peroxides into stable end products.

Nowadays, the interest in antioxidant compounds has increased by recent evidences regarding the important role of antioxidants in human health. Specifically, several preventing effects on different diseases have been related to the consume of antioxidants, such as prevention against cancer, coronary heart diseases, inflammatory 
disorders, neurological degeneration, aging, etc [5,6]. This interest has made necessary the development of new analytical procedures able to handle the everyday more complex matrices in which these compounds are detected. In this sense, capillary electromigration techniques have emerged as a powerful tool, allowing the separation and identification of highly polar compounds that can not be easily separated by traditional HPLC methods, providing complementary information and permitting the simultaneous analysis of analytes with different nature in a single run [7,8]. Besides, capillary electromigration methods generally provides shorter analysis times and higher efficiencies than other techniques requiring lower volumes of sample and reagents.

It is well-known that several separation techniques are comprised under the concept of “capillary electromigration methods" having different operational characteristics and separation principles. These modes of capillary electrophoresis (CE) include capillary zone electrophoresis (CZE), capillary gel electrophoresis (CGE), micellar electrokinetic chromatography (MEKC), capillary electrochromatography (CEC), capillary isoelectric focusing (CIEF) and capillary isotachophoresis (CITP). Although these modes differ in their fundamentals and in the background electrolyte used, all of them have in common that the separation is based on differences in electromigration between analytes under a given electric field.

The aim of this revision is to describe the applications of the different capillary electromigration methods that have been developed so far to analyze natural antioxidants from foods and other natural matrices. As will be shown below, antioxidant compounds have been classified in this review according to their chemical nature (e.g., catechins, isoflavones, anthocyanins, phenolic acids, vitamins, etc) and the natural source in which they have been found. Olive oil as natural source of antioxidants has been expressly excluded from this review since this matrix is specifically studied in another review within this Special Issue.

\section{PHENOLIC COMPOUNDS.}

Phenolic compounds or polyphenols are one of the most important group of compounds occurring in plants, where are widely distributed, comprising at least 8000 different known structures [9]. Polyphenols are also products of the secondary metabolism of plants. These compounds are reported to exhibit anti-carcinogenic, anti-inflammatory, anti-atherogenic, anti-thrombotic, immune modulating, and analgesic activities, among 
others, and exert these functions as antioxidants [10-15]. In general, phenolic compounds can be divided into, at least, ten types depending on their basic structure: simple phenols, phenolic acids, hydroxycinnamic acids, coumarines and isocoumarines, naphtoquinones, xanthones, stilbenes, anthraquinones, flavonoids and lignins. Flavonoids constitute the most important polyphenolic class, with more than 5000 compounds already described [5].

\subsection{Flavonoid compounds.}

Flavonoids are a wide group of phenolic compounds that include into their chemical structure a C6-C3-C6 configuration (see Figure 1). These compounds are broadly found in vegetable matrices, as fruits, seeds or leaves. In these matrices they can be found as either glucosides or aglycones. The antioxidant activity of flavonoids is commonly related to their chemical structure $[10,16,17]$. Concretely, this activity is generally linked with the position and degree of hydrosilation of the $\mathrm{B}$ ring of the general structure (see Figure 1). Usually, aglycones are more active than glycosides, and in general, flavonoids are active as primary antioxidants. A most detailed classification of flavonoids can be stated depending on both the substitution pattern of the $\mathrm{C}$ ring and the position of the B ring (see Figure 1). The main subgroups are flavonols, anthocyanins, flavones, isoflavones, and catechins [18]. Although HPLC has traditionally been the main analytical technique employed for the analysis of this kind of compounds, CE has been pointed out as an adequate tool for the separation and identification of different flavonoids as demonstrated by the many applications of CE in this area (see Table 1).

\subsubsection{Catechins.}

Catechins, also called flavan-3-ols, are a group of flavonoids usually found in plants that have traditionally been indicated to posses beneficial health effects. In a high proportion, health effects from some plants seem to be linked to the antioxidant activity of some of these compounds [12,14]. One of the species that has been studied is sea buckthorn plant (Hippophae rhamnoides L.), a traditional chinese medicinal herb [19]. Chu et al. [19] were capable to identify several catechins together with other flavonoids from this herb by capillary electrophoresis with electrochemical detection. In addition to catechin and epicatechin, rutin, kaempferol and quercitin could be detected using a 60 
$\mathrm{mM}$ borate running buffer at $\mathrm{pH} 9.0$. The voltage was set at $14 \mathrm{kV}$, allowing a complete analysis in less than 21 minutes. For electrochemical detection, a $+950 \mathrm{mV}$ potential was applied to the working electrode.

Concerning the analysis of catechins by CE, tea (Camelia sinensis) has been the most studied plant being catechins the most abundant polyphenols found in tea leaves (up to $30 \%$ of dry mass in some cases) [20]. Several authors have analyzed tea flavonoids by CE [21-29] as can be deduced from the summary given in Table 2. Thus, Horie et al. [21] employed CZE to analyze and determine the major compounds in green tea infusions. (-)-Epicatechin, (-)-epigallocatechin, (-)-epicatechin gallate, (-)epigallocatechin gallate and (+)-catechin were detected using a $77 \mathrm{~cm}$ fused capillary length (70 $\mathrm{cm}$ to detector) and a $20 \mathrm{mM}$ borax buffer at $\mathrm{pH} 8.0$ [21]. In spite of this interesting CZE application to study this group of flavonoids, MEKC has been the technique of choice in almost all cases since MEKC allows the simultaneous separation of neutral and charged solutes in the same run [30]. Thus, the same research group [22] applying MEKC and using a borate buffer with sodium dodecyl sulfate as surfactant (80 $\mathrm{mM}$ sodium tetraborate and $50 \mathrm{mM}$ SDS at $\mathrm{pH}$ 8.4) could identify (-)-epicatechin gallate, (-)-epicatechin, (-)-epigalloatechin and (-)-epigallocatechin gallate among other compounds from different types of tea. Similarly, Larger et al. [23] used MEKC to analyze flavonoids in teas that differ in their production process. For example, while the green tea is a non-fermented product, the black tea suffers a fermentation process during its production. These processes seemed to have a large influence on the flavonoid content [23]. Wright et al. [28,29] proposed two different CE methods to predict the quality of the black tea. The first one was a MEKC method used to detect the catechin content (25 mM phosphate buffer at pH 7.0 with $100 \mathrm{mM}$ SDS and $6 \%$ methanol), and the second a non-aqueous capillary electrophoresis (NACE) method used to analyze the theaflavin content. Theaflavin are dimers formed from catechins by a polyphenol oxidase. The NACE running buffer consisted of $71 \%$ acetonitrile, $25 \%$ methanol with $0.1 \mathrm{M} \mathrm{KOH}, 4$ \% glacial acetic acid and $90 \mathrm{mM}$ ammonium acetate.

Larger et al. [23] could study the chemical composition of green and black tea using MEKC with UV detection at $278 \mathrm{~nm}$ and a running buffer composed of $20 \mathrm{mM}$ SDS, 50 $\mathrm{mM}$ phosphate, $50 \mathrm{mM}$ sodium tetraborate, $10 \%$ acetonitrile at $\mathrm{pH}$ 6.0. Whilst (-)epigallocatechin, (+)-catechin, (-)-epicatechin, (-)-epigallocatechin gallate and (-)epicatechin gallate could be detected among other flavonoids in green tea infusions, only (-)-epicatechin, (-)-epigallocatechin gallate and (-)-epicatechin gallate were found 
in black tea infusions. However, other flavonoids, like kaempferol, appeared in these black tea samples.

As can be seen in Table 2, MEKC methods have frequently been developed by different authors to analyze catechins in several kinds of tea leaves. Thus, Bonoli et al. [27] employed a running buffer composed by phosphate and borate with SDS to detect the seven catechins present in green tea, that is, (-)-gallocatechin, (-)-epigallocatechin, $(+)-$ catechin, (-)-epigallocatechin-3-gallate, (-)-epigallocatechin, (-)-gallocatechingallate and (-)-epicatechingallate. This method was used to establish a comparison between MEKC and HPLC methodologies [26]. Thus, the MEKC method provided high efficiencies, and better resolution (see electropherograms of Figure 2) than HPLC, while HPLC showed a better reproducibility on the quantitative analysis and better sensitivity (LODs were 20-100 times better using HPLC). However, it has to be pointed out the convenience of MEKC in terms of time of analysis (12 minutes against 40 minutes in HPLC) and solvents consumption. These conclusions are also in good agreement with those obtained by Lee et al. [31] who established a similar comparison. In this case [31] the running buffer contained $40 \%$ of $500 \mathrm{mM}$ boric acid, $10 \%$ of 100 $\mathrm{mM}$ potassium dihydrogenphosphate, $22.5 \%$ of $20 \mathrm{mM} \beta$-ciclodextrin and $27.5 \%$ of acetonitrile. CE was much faster than HPLC and more reproducible, and although CE was found to be less sensitive, CE was finally considered both more time and cost effective at long term than HPLC [31]. Furthermore, several other examples can be found in the literature on this type of comparison for antioxidants analysis [32,34].

Procyanidins are oligomeric forms composed of catechin and epicatechin. Some of these compounds were separated by the first time by Cifuentes et al. [35] using an acidic MEKC buffer containing SDS at pH 5. In that work [35], a complete separation of procyanidin B3, procyanidin B1, (+)-catechin, cis-p-coumaric acid, procyanidin B2, trans-p-coumaric acid and (-)-epicatechin was achieved in less than 5 minutes. Furthermore, it was possible to identify some of these phenolic compounds in different food samples like lentils, black beans and almond peels.

\subsubsection{Isoflavones.}

Isoflavones are a group of flavonoids that can be mainly found in soybean. As it occurs with other type of flavonoid compounds, isoflavones are suggested to be responsible of the antioxidant activity attributed to soy and other plant products. Isoflavones such as 
puerarin and daizein have been also analyze in traditional Chinese medicinal herbs using MEKC [36] and CZE methods [37]. Although flavonoids are weak acids, the basis of a hydrophobic separation (as that used in MEKC) has been considered more suitable for their separation. Several studies have been carried out to identify this kind of compounds by means of CE with electrochemical detection [36-38]. The use of this detector provides sensitivity enhancement compared to that obtained from an UV detector. Peng et al. [38] performed the simultaneous detection of daizein and genistein, the most important isoflavones in soy, using an electrochemical detector coupled to a capillary electrophoresis instrument (the separation was carried out in a $100 \mathrm{mM}$ borate buffer at a relatively high pH of 11.0). Mellenthin et al. [39] applied a CZE method developed by Shihabi et al. [40] to the separation of soy isoflavones establishing a comparison between this CZE separation and the analysis performed by HPLC. By using a $200 \mathrm{mM}$ boric acid buffer at $\mathrm{pH}$ 8.6, the separation achieved was almost six times faster than that obtained by HPLC. In contrast, the reproducibility was relatively worse. In spite of that, daidzin, genistin and their respective malonyl and acetyl glycosides could be identified in the soy samples as well as daidzein and genistein. In addition to the analysis of the real samples, more complex separations have been achieved from mixtures of standards [41] being able to separate six different isoflavones using CZE with a borate buffer and diode array detection.

\subsubsection{Anthocyanins.}

Anthocyanins are the largest group of hydro-soluble pigments occurring in nature. Besides their characteristic colour, several functional activities have been attributed to this group of compounds [42], including their antioxidant activity [43,44]. HPLC has been the preferred method to analyze anthocyanins [42] and only few applications have been developed using capillary electrophoresis. One of these applications was carried out by Bridle et al. [45] for the separation of anthocyanins from strawberry and elderberry by CE and HPLC, concluding that HPLC was the most favourable technique for this type of analysis in terms of sensitivity. Ichiyanagui et al. [46] demonstrated the different anthocyanins distribution among different bilberry sources. The separation of anthocyanins was successfully achieved using a $30 \mathrm{mM}$ borate buffer with $7.5 \mathrm{mM}$ CyDTA (trans-1,2-diamino-cyclohexane-tetra acetic acid monohydrate) at $\mathrm{pH}$ 8.8. Even though in these works separations were achieved by CZE, the results suggested that the 
use of an acidic buffer would be necessary to improve the separation [45]. These acidic conditions were tested by Costa et al. [47] to separate the four main anthocyanins present in blackcurrant (Ribes nigum). The method was optimized, and a phosphate buffer at pH 1.5 with $30 \%$ acetonitrile was used. Although coated capillaries were also tested, the best results were obtained using an uncoated fused silica capillary. In this sense, the importance of the separation $\mathrm{pH}$ in order to obtain an adequate resolution of this type of compounds was also mentioned in some other works $[48,49]$. Thus, small $\mathrm{pH}$ changes caused important variations in migration times and resolution of anthocyanins. Moreover, the strong acidic value of $\mathrm{pH}$ was useful to preserve the cationic forms and to maintain the stability of the compound structures (i.e. when flavilium cation dominates). Nevertheless, analysis of this type of compounds in a basic medium was also demonstrated later [50]. In that work [50], wine samples were analyzed to quantitatively determine their anthocyanins content. By means of a $50 \mathrm{mM}$ tetraborate buffer at $\mathrm{pH} 8.4$ with $15 \%$ of methanol, the separation of several anthocyanins was achieved from real samples, with results comparable to those obtained by HPLC but with minimum set-up time. The detection was made at $599 \mathrm{~nm}$ because the chemical structures of solutes presented a blue quinoidal base at the running buffer $\mathrm{pH}$.

\subsubsection{Other flavonoids.}

Concerning the rest of the groups belonging to the flavonoid family, several CE techniques have been applied to their separation and identification. Among them, the most used technique has been CZE. By using this technique, relatively complex separations of flavonols present in fruit juices and wines have been achieved [51-53]. In one of the first examples published on this kind of separations, Fernández et al. [51] developed a CZE method able to separate kaempherol-3-rutinoside, rutin, avicularin, quercitin, isoquercitin, isohamnetin, kaempherol and quercitrin in less than 10 minutes. In a more recent study [52], nine flavonoids were determined in wine. Namely, apigenin, baicalein, naringenin, luteolin, hesperidin, galangin, kaempferol, quercetin and myricetine were separated in about 15 minutes using a $35 \mathrm{mM}$ borax buffer at $\mathrm{pH}$ 8.9, as can be seen in Figure 3. Separation of several flavonoids and phenolic compounds was also studied by Fonseca et al. [54]. It was found that the best separations conditions for apigenin, luteolin, naringenin, rutin, quercetin, umbelliferone, 
herniarin, chlorogenic acid and caffeic acid were achieved using a $20 \mathrm{mM}$ tetraborate buffer at pH 10.0 with UV detection at $337 \mathrm{~nm}$.

Other study has revealed the possibility to apply capillary electromigration methods to separate diastereomers of flavanone-7-O-glycosides [55]. Namely, authors demonstrated the usefulness of sulfobutyl ether- $\beta$-ciclodextrin (SBE- $\beta C D, 7.5 \mathrm{mg} / \mathrm{ml}$ in buffer) as chiral selector in a $20 \mathrm{mM}$ tetraborate ( $\mathrm{pH}$ 7.0, $10 \%$ methanol) running buffer to separate the diastereomers of narangin, hesperidin, neohesperidin, narirutin and eriocitrin standards [55].

Cao et al. [56] analyzed Ginkgo biloba flavonoids using electrochemical detection. Epicatechin, catechin, rutin, apigenin, luteolin and quercetin were found in this plant, demonstrating once more the suitability of this technique compared to the more traditional HPLC procedure. As above, a number of reports have demonstrated that MEKC is also a suitable technique for separation of different antioxidants from foods. One example is the work by Rodriguez-Delgado et al. [57] in which the determination of several flavonoids in wine samples was described. Thus, the use of a high electrolyte concentration buffer along with a medium SDS concentration and the addition of a small proportion of methanol drawn to the most favourable combination [57]. Honey and other related products like propolis have been also widely studied using both, CZE [58,59] and MEKC [60-62]. One of the main flavonoids found in propolis is rutin. This compound has also been determined in samples from Buckwheat (Fagopyrum esculentum Moench) using MEKC [63].

\subsection{Phenolic acids and other phenolic compounds.}

Besides flavonoids, other type of phenolic compounds can be found in vegetable matrices, for instance, phenols, phenolic acids, stilbenes, lignins, xanthones, etc...[5]. Interestingly from a literature search it can be concluded that, regarding the study of phenolic compounds, one of the phenolic compounds more frequently studied has been resveratrol (mostly in grapes, and grapes related products, including wine), for this reason a special section is devoted below to this compound.

\subsubsection{Resveratrol.}


Among all the possible compounds that can be detected in grapes and wines, resveratrol has been one of the most (if not the most) frequenlty investigated substance [64]. This compound shows antioxidant activity [65] and has also been examined by its anticarcinogenic [66], heart disease prevention [67] and antibiotic [68] activities. Resveratrol exists in two isomeric forms, cis and trans. It seems that the trans form is the responsible of the physiological activities and that it is transformed into the cis form under UV light. For these reasons, resveratrol has been analyzed by several techniques including CE. Hence, several electromigration techniques have been employed to its determination. CZE has been used by Berzas et al. [67] to determine the content of cis and trans resveratrol from wine extracts, obtaining detection limits of 0.08 and 0.06 $\mathrm{mg} / \mathrm{mL}$, respectively. Gao et al [68] proposed a method, without previous extraction, that could directly detect trans resveratrol in wine using an electrochemical detector. So, this method was suggested as an alternative to the traditional HPLC methods to detect trans resveratrol in real samples. Other alternatives, as for instance the coupling of CE with luminescence spectroscopy [69], has been proposed to analyze these isomers. In this novel system [69], a nonaqueous CE buffer was used to separate the cis and trans isomers, developing a special device that allows the coupling between the CE system and the low temperature luminescence detector.

In other works [65,70], MEKC has been the technique of choice to analyze resveratrol. Thus, using a UV detector and a separation buffer at $\mathrm{pH} 9.0$ with SDS, limits of detection of $1.25 \mu \mathrm{M}$ have been achieved for this compound [65]. These results were later improved by the use of a solid phase extraction step previous to the determination by MEKC [71]. In this case, limits of detection of 0.1 and $0.15 \mu \mathrm{M}$ for trans and cis resveratrol, respectively, were reached.

\subsubsection{Other phenolic compounds.}

Several works have studied the different composition, regarding the phenolic compounds profile, of different wine samples of different varieties [72-79]. Thus, several phenolic compounds such as epicatechin, catechin, epigallocatechin, syringic acid, coumaric acid, vanillic acid, caffeic acid, gallic acid, p-coumaroyl tartaric acid and dihydroxybenzoic acid, among others [72,74,75] have been determined in wines using CZE with UV detection at $280 \mathrm{~nm}$ and others detection lengths Moreover, the determination of phenolic compounds in wines has also been carried out using 
electrochemical detection [78]. In this case, the potential of the working electrode had to be carefully optimized, since this factor affected directly to the sensitivity and stability of the method. Applying a potential of $+0.85 \mathrm{~V}$ it was possible to reach limits of detection down to $2.0 \times 10^{-7} \mathrm{~g} / \mathrm{ml}$ for trans-resveratrol, epicatechin and catechin. Also, an automated sample preparation procedure prior to capillary electrophoresis has been applied to separate eight phenolic compounds along with resveratrol [80]; in that work a flow injection (FI) system using a C-18 column is applied to clean-up the sample before its automatic introduction into the CE instrument. The FI-CE method developed was applied to analyze phenolic compounds in wines, providing detection limits between 0.05-0.36 mg/L.

In a work by Andrade et al [81], a group of phenolic compounds were analyzed in different wines by using CE and HPLC. Thus, although no significant quantitative or qualitative differences were detected between the results provided by both techniques, CE was selected for the routine analysis of these samples because it provides higher efficiency and speed than HPLC [81].

Yanes et al. [82] separated and identified seven polyphenols in grape seeds, including resveratrol, several catechins and gallic acid, using as buffer tetraethylammonium tetrafluoroborate (TEA-TFB). The method provided an excellent reproducibility because of the capillary wall coating formed by the tetraethylammonium cations. This coating allowed a non $\mathrm{pH}$ dependent separation.

Capillary electrophoresis coupled with mass spectrometry detection (CE-MS) has also been employed to analyze wine extracts, namely, to detect phenolic compounds [83]. The use of MS as CE detector provides a number of additional advantages, as for instance the possibility to obtain structural information and molecular weights of the compounds analyzed as well as information about the identity of co-migrating compounds. In that work [83], CE-MS was shown to provide poorer sensitivity than LC-MS when applied to the analysis of this type of compounds.

A CE method was optimized to detect twenty-six phenolic compounds previously reported to be present in honey. Using a $100 \mathrm{mM}$ borate buffer at $\mathrm{pH} 9.5$ with $20 \%$ methanol, it was possible to establish a relationship between the floral origin of the honeys and the phenolic compounds found in their composition [84].

Furthermore, MEKC has been applied to the detection of phenolic compounds from different herbal matrices [85]. Thus, using a $20 \mathrm{mM}$ tetraborate acid containing $20 \mathrm{mM}$ 
SDS, it was possible to analyze 18 different phenolic compounds determining also their partition coefficients and solute-micelle association constants [85].

Several works have been carried out to separate different phenolic compounds from rosemary (Rosmarinus officinalis). The high antioxidant activity of this plant [86] seems to be mainly related to two phenolic compounds, rosmarinic acid and carnosic acid [87]. Two CE methods have been developed to separate and identify carnosol and carnosic acid [88] and carnosic and rosmarinic acids [89]. Both methods were similar and provided faster analysis than HPLC, but did not allow the identification of other minor compounds present in the sample due to the inferior sensitivity of CE methods compared with HPLC. An improved method was later proposed by Crego et al. [90] using a $50 \mathrm{mM}$ borate buffer at pH 9.5 and $10 \%$ acetonitrile. By using these conditions [90], it was possible to detect and separate carnosol, rosmarinic acid, carnosic acids, genkwanin and rosmanol from subcritical water rosemary extracts. Apart of CZE, MEKC has also been proposed to analyze rosemary extracts [91]. This MEKC procedure allowed the determination of rosmanol, carnosol, carnosol isomer, carnosic acid and methyl carnosate by using a $20 \mathrm{mM}$ sodium tetraborate running buffer with 50 mM sodium deoxycholate as surfactant and $15 \%$ acetonitrile, providing complementary results to HPLC analysis [91]. Further optimization was carried out in order to chracterize the compounds from this type of extracts by CE coupled to mass spectrometry (CE-MS) [92]. In order to do that, a new CE method has to be developed able to compatibilize the CE separation conditions (mostly, using volatile separation buffer) with the subsequent MS detection step. An exhaustive optimization of all the factors involved in the nebulization-ionization step such as sheath liquid composition and sheath liquid rate, dry gas temperature and flow and nebulizer gas pressure was carried out. Isoquercitrin, carnosic acid, rosmarinic acid, homoplantagenin and gallocatechin were detected in these extracts as can be seen in Figure 4. This method allowed the characterization of several rosemary extracts obtained at different extraction conditions, since the composition of rosemary extracts changed as a function of the extraction temperature used in the subcritical water extraction step.

Another important phenolic acid is caffeic acid. This compound is usually found in foods as chlorogenic acid (i.e., the ester form of caffeic acid). Caffeic acid is present in high amounts in coffee along with other polyphenols such as ferulic acid and $p$ coumaric acid. Several works have investigated the influence of different parameters in the coffee production concerning these antioxidants by means of CE [93-95]. In these 
works, borate at different concentrations $(50,100 \mathrm{mM})$ and at $\mathrm{pH} 9.5$ is typically used as separation buffer. Caffeic acid, ferulic acid, p-coumaric acid, chlorogenic acids and several hydroxycinnamic acids could be detected under these conditions. Other phenolic acids have been determined using MEKC, as for instance 1-O-glycopyranosyl sinapate [96] that was detected in rapeseed using $\beta$-cyclodextrins added into the running buffer. CZE has also been employed for routine analysis of phenolic compounds in different matrices including extracts from Eucommia ulmoides and alcoholic beverages $[97,98]$.

Detection of anthraquinones, a type of phenolic compounds, from rhubarb, a traditional Chinese medicinal herb, was presented by Ding et al. [99], In that work, authors proposed a CEC method in which capillary electrochromatography columns are prepared using HPLC stationary phases, applying the CEC columns to the separation of five anthraquinones. Packing of CEC columns was done by placing a frit fabricated with silica gel particles at the end of the capillary, and then connected to a vacuum pump while the other end was placed into an acetonitrile solution with ODS particles. The CEC mobile phase consisted of $2.0 \mathrm{mM}$ phosphate and $4.0 \mathrm{mM}$ MES (morpholineethanesulphonic acid) buffer with 80 \% acetonitrile and allowed the baseline separation of the five anthraquinone compounds in less than 11 minutes.

\section{VITAMINS.}

Among the vitamins with antioxidant activity, ascorbic acid has played an important role in the food industry since this compound has traditionally been employed to prevent food deterioration. Several CE works have focussed on the separation and detection of ascorbic acid and other vitamins [100-102] while other works have been devoted to determine the amount or presence of L-ascorbic and D-isoascorbic acids [103-106] in different foods. While L-ascorbic acid is contained in most vegetables and fruits, D-isoascorbic acid does not naturally exist in foods being used as an additive due to its antioxidant activity. This point, together with the fact that D-isoacorbic acid has only a $5 \%$ of the L-ascorbic activity [104], has made of this separation an interesting goal in food analysis. These compounds have successfully been separated as standards by CZE using a $0.2 \mathrm{M}$ borate buffer at $\mathrm{pH} 9.0$ [103], from plant tissues using a similar running buffer [105], and from juices using a $50 \mathrm{mM}$ tricine buffer at $\mathrm{pH} 8.8$ [104], with limits of detection of 1.6 and $1.1 \mathrm{mg} / \mathrm{L}$ for L-ascorbic acid and D-isoascorbic acid, respectively [104]. A method based on MEKC using sodium deoxycholate as micellar 
agent was proposed by Thompson et al. to replace the HLPC method used to analyze Lascorbic acid [107]. After a few extraction steps, L-ascorbic acid could be determined in the fruits and vegetables analyzed in that study [107]. Similarly, Buskov et al. achieved the separation of ascorbic acid and others vitamins by MEKC [108]. Likewise, sodium dodecyl sulfate together with sodium deoxycholate have been tested as micellar phase to separate ascorbic acid and other antioxidants [109]. Thus, it could be demonstrated that mixed micellar phases can be used to separate mixtures of antioxidants with different and similar polarities.

CZE has been used to detect ascorbic acid in several vegetables with detection limits of $0.35 \mathrm{mg} / \mathrm{L}$ [110]. Also CZE was used to detect ascorbic acid in several fruits, juices and vegetables with LOD about $0.25 \mathrm{mg} / \mathrm{L}$ [111]. Detection of ascorbic acid together with other flavonoids in citrus juices has also been carried out by CZE [112].

Capillary isotachophoresis (CITP), the CE mode in which solutes separation is achieved between two different electrolytes [113], has not frequently been applied to separate natural antioxidants. Sadecká et al. [106] developed an isotachophoresis method with conductivity detection (using hydrochloric acid, $\beta$-alanine and methylhydroxyethylcellulose in the leading electrolyte, and caproic acid as terminating electrolyte) to determine ascorbic acid and some food additives in fruit juices and beer. Although most research concerning antioxidant vitamins is related to ascorbic acid, several authors have studied the separation of other vitamins as tocopherols. In this case, capillary electrochromatography (CEC) has been the technique of choice. Fanali et al. [114] achieved the baseline separation of $\delta$-, $\gamma$ - and $\alpha$-tocopherol bt CEC using an octadecylsilica stationary phase and a mobile phase composed by ammonium acetate, methanol and acetonitrile (see Figure 5). It was found that CEC separation was strongly dependent on the organic solvents and their proportion. Moreover, this method took advantage from HPLC since consumption of mobile phase by CEC was minimum compared to HPLC; also the analysis time required was shorter and the efficiency reached higher. In addition, separation of tocopherols that are present in vegetables oils has been carried out by CEC [115]. In that work [115], different mobile phases, stationary phases and electric fields were tested in order to achieve the separation of several tocopherols and tocotrienols standards. The method developed was presented as a viable alternative to the currently existing HPLC methods for the routine analysis of tocopherols and tocotrienols in palm oil or rice bran oil. 


\section{OTHER ANTIOXIDANTS.}

Indolyl glucosinates are broadly distributed in Brassica plants. These compounds and their degradation products seem to have beneficial health effects that can be related to their antioxidant activity. A MEKC method was developed to separate a mixture of up to fifteen of these compounds [116]. To this purpose, a $18 \mathrm{mM}$ borate and $30 \mathrm{mM}$ phosphate running buffer at pH 7.0 with $10 \%$ 2-propanol was employed using $50 \mathrm{mM}$ of didecyltrimethylammonium bromide as micellar phase.

Usually, Maillard reaction occurs in food processing when a compound with a free amino acid group reacts with a reducing carbohydrate or its degradation products. Melanoidins are a type of Maillard reaction products responsible for the colour of the processed and cooked foods. It has been demonstrated that some of these compounds have good antioxidant activity [117] being some of them analyzed by CZE $[118,119]$. Besides, the analysis of antioxidant proteins or peptides [120] has been also carried out by CE. A type of proteins with marked antioxidant characteristic are phycobiliproteins. These proteins are usually found in blue-green microalgae (Cyanobacteria) being their antixodant activity linked to the chromophore covalently linked to the peptidic chain of these proteins. Antioxidant activity as well as other beneficial effects derived from these proteins have been shown by several authors [121,122]. Extraction of these proteins and their subsequent analysis are therefore interesting issues. Viskari et al. [123] have developed a capillary electrophoresis method with laser induced fluorescence (LIF) to analyze phycobiliproteins using a $50 \mathrm{mM}$ borate and $11.7 \mathrm{mM}$ phytic acid buffer at $\mathrm{pH}$ 8.15 with the detection set at $630 \mathrm{~nm}$ (excitation $594 \mathrm{~nm}$ ). As expected, LIF detection provided more sensitive and selective detection than UV absorbance. This CZE-LIF method was applied to analyze different extracts obtained using several extraction techniques as well as to tentatively identify the proteins in the electropherograms by means of differences in the absorption profiles. Further identification of the phycobiliproteins extracted from Spirulina platensis has recently carried out by our group [124]. To do this, CZE coupled to two different MS analyzers was employed (namely, CE-ESI-ion trap-MS and CE-ESI-time of flight-MS) using as running buffer a $40 \mathrm{mM}$ ammonium hydrogen carbonate at $\mathrm{pH} 7.8$ with acetonitrile and propanol (40:50:5, v/v/v). Ion trap is the most frequently employed MS analyzer in CE-MS because of its cost, scan speed, and the possibility to perform MS-MS. On the other hand, time of flight analyzer provides much better resolution, similar sensitivity and 
higher scan speed than the ion trap. Therefore, the combined use of both MS analyzers gives rise to a very powerful analytical tool that allows the determination of different phycobiliproteins from this microalga.

Apart of phycobiliproteins, other antioxidant compounds have been found in Spirulina platensis microalga. Thus, Herrero et al. [125] have studied the composition of PLE (pressurized liquid extraction) extracts from Spirulina platensis obtained with different solvents. A MEKC method was developed to allow in a fast way (based on the UV-Vis spectra of the different compounds provided by a diode-array detector) the tentative characterization of the extracts followed by in-vitro assays of their antioxidant activity.

\section{CONCLUSIONS AND FUTURE OUTLOOKS.}

The use of capillary electromigration methods to analyze antioxidants from natural origin is nowadays increasing, although HPLC is still the technique of choice to study this type of compounds. The high resolution, efficiency and analysis speed provided by CE together with the minimum sample and reagents consumption have promoted the use of this technique. The versatility and variety of CE separation principles, the ability to adapt them to solve different analytical problems as well as the CE suitability to be coupled to different types of detectors have made of CE a powerful tool for the characterization of natural antioxidants. It has also to be taken into account that $\mathrm{CE}$ techniques usally provide complementary information to that from chromatographic procedures. Nevertheless, some problems of reproducibility of CE methods have still to be overcome mostly when applied to real life samples (e.g., by developing and using proper validation methods). Moreover, the sensitivity problems from CE need to be further investigated and improved. By doing this, CE will become a real alternative to the most consolidated chromatographic techniques based on HPLC.

In our opinion, the true potential of this group of electromigration techniques has not been fully achieved yet since CE can play an important role in many fields related to the analysis of antioxidant compounds (e.g., through the development of in-column CE methodologies to determine "in-vitro" the antioxidant activity of new compounds in a fast, automatic and cheap way).

Moreover, the more advanced CE technologies have to be also demonstrated in the area of natural antioxidants. For instance, the use of CE-MS is very rare in this area, likewise, at the moment no antioxidant application has been described using CE on 
microchips. Perhaps the future affordability of these instruments and technologies will make them more common to these purposes.

\section{ACKNOWLEDGEMENTS}

$\mathrm{MH}$ would like to thank MCYT for a FPI grant. Authors thank MCYT (project AGL2002-04621-C02-02) for financial support. 


\section{REFERENCES}

[1] I. Goldberg. Functional foods. Designer foods, pharmafood, nutraceuticals. Chapman and Hall, London, UK, 1996.

[2] M. Herrero, A. Cifuentes, E. Ibáñez, Food Chem., 2004, submitted for publication.

[3] D.L. Madhavi, R.S. Singhai, P.R. Kulkarni, in: Food Antioxidants, D.L. Madhavi, S.S. Deshpande, D.K. Salunkhe (ed.), Marcel Dekker, New York 1996, p 159.

[4] D. Rajalakhmi, S. Narasimham, in: Food Antioxidants, D.L. Madhavi, S.S. Deshpande, D.K. Salunkhe (ed.), Marcel Dekker, New York 1996, p 65.

[5] J. Wollgast, E. Anklam, Food Res. Int. 2002, 33, 423-447.

[6] D.V. Madhavi, S.S. Despande and D.K. Salunkhe, in Food antioxidants, D.L. Madhavi, S.S. Deshpande, D.K. Salunkhe (ed.). Marcel Dekker, New York 1996, p.1

[7] C. Simó, E. Ibañez, F.J. Señorans, C. Barbas, G. Reglero, A. Cifuentes, J. Agric. Food Chem. 2002, 50, 6648-6652.

[8] W. Zheng, S.Y. Wang, J. Agric. Food Chem., 2001, 49, 5165-5170.

[9] L. Bravo, Nutr. Rev., 1998, 56, 317-333.

[10] A.L. Catapano, Angiology, 1997, 48, 39-44.

[11] A.E. Hagerman, K.M. Riedl, G.A. Jones, K.N. Sovik, N.T. Ritchard, P.W. Hartfeld, T.L. Riechel, J. Agric. Food Chem., 1998, 46, 1887-1892.

[12] K. Ioku, T. Tsushida, Y. Takei, N. Nakatani, J. Terao, Biochim. Biophys. Acta, 1995, 1234, 99-104.

[13] N.Salah, N.J. Millar, G. Paganga, L. Tijburg, G.P. Bolwell, C. Rice-Evans, Arch. Biochem. Biophys., 1995, 322, 339-346.

[14] M. Serafini, A. Ghiselli, A. Ferro-Luzzi, Eur. J. Clin. Nutr., 1996, 50, $28-32$.

[15] J.A. Vinson, Y. Hao, X. Su, L. Zubik, J. Agric. Food Chem., 1998, 46, 3630-3634.

[16] D.E. Pratt, B.J. Hudson, in: Food Antioxidants. B.J.F. Hudson (Ed.) Elsevier Applied Science, London, 1990, p.171.

[17] C.A. Rice-Evans, N.J. Miller, G. Paganga, Free Radic. Biol. Med., 1996, 20, 933956.

[18] H.M. Merken, G.R. Beecher, J. Chromator A. 2000, 897, 177-184.

[19] Q.C. Chu, W.Q. Qu, Y.Y. Peng, Q.H. Cao, J.N. Ye, Chromatographia, 2003, 58, 67-71.

[20] J.P. Aucamp, Y. Hara, Z. Apostolides, J. Chromatogr. A, 2000, 876, 235-242.

[21] H. Horie, T. Mukai, K. Kohata, J. Chromatogr. A, 1997, 758, 332-335. 
[22] H. Horie, K. Kohata, J. Chromatogr A, 1998, 219-223.

[23] P.J. Larger, A.D. Jones, C. Dacombe, J. Chromatogr. A, 1998, 799, 309-320.

[24] C.C: Wörth, M. Wiessler, O.J. Schmitz, Electrophoresis, 2000, 21, 3634-3638.

[25] L. Arce, A. Ríos, M. Valcárcel, J. Chromatogr. A, 1998, 827, 113-120.

[26] M. Bonoli, M. Pelillo, T.G. Toschi, G. Lercker, Food Chem. 2003, 81, 631-638.

[27] M. Bonoli, P. Colabufalo, M. Pelillo, T.G. Toschi, G. Lercker, J. Agric. Food Chem. 2003, 51, 1141-1147.

[28] L.P. Wright, N. Mphangwe, H.E. Nyiernda, Z. Apostolides, J. Sci. Food Agric, 2000, 80, 1823-1830.

[29] L.P. Wright, N. Mphangwe, H.E. Nyrenda, Z. Apostolides, J. Sci. Food Agric, 2002, 82, 517-525.

[30] S. Terabe, K. Oksuka, K. Ichikawa, A. Tsuchiya, T. Ando, Anal. Chem., 1984, 56, 111-113.

[31] B.L. Lee, C.N. Ong, J. Chromatogr. A, 2000, 881, 439-447.

[32] P.G. Pietta, P.L. Mauri, R.G: Sabbatini, J. Chromtatogr. A, 1991, 549, 367-373.

[33] C.A. Hall III, A. Zhu, M.G. Zeece, J. Agric. Food Chem. 1994, 42, 919-921.

[34] F.A. Tomás-Barberán, C. García-Viguera, Analusis, 1997, 25, M23-M25

[35] A. Cifuentes, B. Bartolomé, C. Gómez-Cordovés, Electrophoresis, 2001, 22, 15611567.

[36] Y. Cao, C. Lou, X. Zhang, Q. Chu, Y. Fang, J. Ye, Anal. Chim. Acta, 2002, 452, 123-128.

[37] G. Chen, J. Zhiang, J. Ye, J. Chromatogr A, 2001, 923, 255-262.

[38] Y. Peng, Q. Chu, F. Liu, J. Ye, Food Chem., 2004, 87, 135-139.

[39] O. Mellenthin, R. Galensa, J. Agric Food Chem., 1999, 47, 594-602.

[40] Z.K. Shihabi, T. Kute, L.L. García, M. Hinsdale, J. Chromatogr. A, 1994, 680, 181-185.

[41] J. Moravcová, T. Kleinová, Czech J. Food Sci., 2001, 19, 132-138.

[42] G. Mazza, J.E. Cacace, C.D. Kay, J. AOAC Int., 2004, 87,129-145.

[43] G. Mazza, C.D. Kay, T. Cottrell, B.J. Holub, J. Agric. Food Chem., 2002, 50, 7731-7737.

[44] K. Robards, P.D. Prenzler, G. Tucker, P. Swatsitang, W. Glover, Food Chem., 1999, 66, 401-436.

[45] P. Bridle, C. García-Viguera, Food Chem., 1997, 59, 299-304. 
[46] T. Ichiyanagi, C. Tateyama, K. Oikawa, T. Konishi, Biol. Pharm. Bull., 2000, 23, 492-497.

[47] C. da Costa, B.C. Nelson, S.A. Margolis, D. Horton, J. Chormatogr. A, 1998, 799, 321-327.

[48] V. Bicard, A. Fougerousse, R. Brouillard, J. Liq. Chrom. \& Rel. Technol., 1999, 22, 541-550.

[49] D.J. Watson, A.A. Bushway, R.J. Bushway, J. Liq. Chrom. \& Rel. Technol., 2004, 27, 113-121.

[50] R. Sáenz-López, P. Fernández-Zurbano, M.T. Tena, J. Chromatogr. A, 2003, 990, 247-258.

[51] B. Fernández, I. Estrella, T. Hernández, Chromatographia, 1995, 41, 389-392.

[52] S.P. Wang, K.J. Huang, J. Chromatogr. A, 2004, 273-279.

[53] H.R. Liang, H. Vuorela, P. Vuorela, M.L. Riekkola, R. Hiltunen, J. Chromatogr. A, 1998, 798, 233-242.

[54] F.N. Fonseca, M.J. Kato, L. Oliveira, N.P. Neto, M.F.M. Tavares, J. Microcolumn Sep., 2001, 13, 227-235

[55] Z. Aturki, M. Sinibaldi, J. Sep. Sci, 2003, 26, 844-850.

[56] Y. Cao, Q. Chu, Y. Fang, J. Ye, Anal. Bioanal. Chem., 2002, 374, $294-299$.

[57] M.A. Rodriguez-Delgado, J. Perez, M.J. Sánchez, F.J. García-Montelongo, Chromatographia, 2000, 52, 289-294.

[58] H. Chi, A.K. Hsieh, C.L. Ng, H.K. Lee, S.F.Y. Li, J. Chromatogr. A, 1994, 680, 593-597.

[59] Y.H. Cao, Y. Wang, Q. Yuan, Chromatographia, 2004, 59, 135-140.

[60] F. Ferreres, M.A. Blazquez, M.I. Gil, F.A. Tomás-Barberán, J. Chromatogr A, 1994, 669, 268-274.

[61] C. Delgado, F.A. Tomás-Barberán, T. Talou, A. Gaset, Chromatographia, 1994, $38,71-78$.

[62] J.D. Fontana, M. Passos, MH.R. dos Santos, C.K. Fontana, B.H. Oliveira, L. Schause, R. Pontarolo, M.A. Barbirato, M.A. Ruggiero, F.M. Lanças, Chromatographia, 2000, 52, 147-151.

[63] S. Kreft, M. Knapp, I. Kreft, J. Agric. Food Chem., 1999, 47, 4649-4652.

[64] X. Gu, Q. Chu, M. O’Dwyer, M. Zeece, J. Chromatogr. A, 2000, 881, 471-481

[65] Q. Chu, M. O’Dwyer, M.G. Zeece, J. Agric. Food Chem., 1998, 46, 509-513. 
[66] M. Jang, L. Cai, G.O. Udeani, K.V. Slowing, C. F. Thomas, C.W.W. Beecher, H.H.S. Fong, N.R. Farnsworth, A.D. Kinghorn, Science, 1997, 275, 218-220.

[67] J.J. Berzas, A. M. Contento, G. Castañeda, Analyst, 1999, 124, 61-66.

[68] L. Gao, Q. Chu, J. Ye, Food Chem., 2002, 78, 255-260.

[69] C.H. Lin, Y.L. Chung, Y.H. Chen, Analyst, 2001, 126, 302-305.

[70] V. Brandolini, A. Maietti, P. Tedeschi, E. Durini, S. Vertuani, S. Manfredini, J. Agric. Food Chem., 2002, 50, 7407-7411.

[71] X. Gu, L. Creasy, A. Kester, M. Zeece, J. Agric. Food Chem., 1999, 47, 32233227.

[72] M.I. Gil, C. García-Viguera, P. Bridle, F.A. Tomás-Barberán, Z. Lebensm. Unters. Forsch., 1995, 200, 278-281.

[73] B.C. Prasongsidh, G.R. Skurray, Food Chem., 1998, 62, 355-358.

[74] P. Andrade, R. Seabra, M. Ferreira, F. Ferreres, C. García-Viguera, Z. Lebensm. Unters. Forsch., 1998, 206, 161-164.

[75] C. García-Viguera, P. Bridle, Food Chem., 1995, 54, 349-352

[76] M. Vaher, M. Koel, J. Chromatogr. A, 2003, 990, 225-230.

[77] R.C. Minussi, M. Rossi, L. Bologna, L. Cordi, D. Rotilio, G.M. Pastore, N. Durán, Food Chem., 2003, 82, 409-416.

[78] Y. Peng, Q. Chu, F. Liu, J. Ye, J. Agric. Food Chem., 2004, 52, 153-156.

[79] A. Panosian, G. Mamikonyan, E. Gabrielyan, S. Mkhitaryan, Anal. Chem., 2001, 73, 4379-4383.

[80] L. Arce, M.T. Tena, A. Ríos, M. Valcárcel, Anal. Chim. Acta, 1998, 359, 27-38.

[81] P.B. Andrade, B.M. Oliveira, R.M. Seabra, M.A. Ferreira, F. Ferreres, C. GarcíaViguera, Electrophoresis, 2001, 22, 1568-1572.

[82] E.G. Yanes, S.R. Gratz, A.M. Stalcup, Analyst, 2000, 125, 1919-1923.

[83] G. Vanhoenacker, A. De Villiers, K. Lazou, D. De Keukeleire, P. Sandra, Chromatographia, 2001, 54, 309-315.

[84] P. Andrade, F. Ferreres, M.I. Gil, F.A. Tomás-Barberán, Food Chem., 1997, 60, 79-84.

[85] G.A. Micke, E.P. Moraes, J.P.S. Farah, M.F.M. Tavares, J. Chromatogr. A, 2003, 1004, 131-143.

[86] J.R. Chipault, G.R. Mizuno, J.M. Hawkins, W.O. Lundberg, Food Res., 1952, 17, 46-52. 
[87] F.J. Señoráns, E. Ibañez, S. Cavero, J. Tabera, G. Reglero, J. Chromatogr. A, 2000, 870, 491-499.

[88] R. Sáenz-López, P. Fernández-Zurbano, M.T. Tena, J. Chromatogr. A, 2002, 953, 251-256.

[89] M. Bonoli, M. Pelillo, G. Lercker, Chromatographia, 2003, 57, 505-512.

[90] A.L. Crego, E. Ibáñez, E. García, R. Rodríguez de Pablos, F.J. Señoráns, G. Reglero, A. Cifuentes, Eur. Food Res. Technol., 2004, 219, 549-555.

[91] E. Ibañez, A. Cifuentes, A.L. Crego, F.J. Señoráns, S. Cavero and G. Reglero, J. Agric. Food Chem., 2000, 48, 4060-4065.

[92] M. Herrero, D. Arráez, A. Segura, E. Kenndler, B. Gius, M.A. Raggi, E. Ibañez, A. Cifuentes, J. Chromatogr. A, 2004, in press.

[93] M.D. del Castillo, J.M. Ames, M. H. Gordon, J. Agric. Food Chem., 2002, 50, 3698-3703.

[94] P.Charurin, J.M. Ames, M.D. del Castillo, J. Agric. Food Chem., 2002, 50, 37513756.

[95] S. Casal, P.B. Andrade, M.O. Oliveira, F. Ferreres, C. García-Viguera, M.A. Ferreira, J. Liq. Chrom. Rel. Technol., 1999, 22, 513-521.

[96] R. Amarowicz, P.P. Kolodziejczyk, Nahrung/Food, 2001, 45, 62-63.

[97] A. Kulomaa, H. Siren, M.L. Riekkola, J. Chromatogr. A, 1997, 781, 523-532.

[98] M.R. Bronze, L.F.V. Boas, A.P. Belchior, J. Chromatogr. A, 1997, 768, 143-152.

[99] J. Ding, B. Ning, G. Fu, Y. Lu, S. Dong, Chromatographia, 2000, 52, 285-288.

[100] C.H. Wu, Y.S. Lo, Y.H. Lee, T.I. Lin, J. Chromatogr. A, 1995, 716, 291-301.

[101] J. Schiewe, Y. Mrestani, R. Neuber, J. Chromatogr. A, 1995, 717, 255-259.

[102] X. Xiong, S.F.Y. Li, J. Chromatogr. A, 1998, 822, 125-136.

[103] T. Liao, J. Swi-Bea, M.C. Wu, H.M. Chang, J. Agric. Food Chem., 2000, 48, 3741.

[104] A. Versari, A. Mattiloli, G.P. Parpinello, S. Galassi, Food Control, 2004, 15, 355358.

[105] M.W. Davey, G. Bauw, M.V. Montagu, Anal. Biochem., 1996, 239, 8-19.

[106] J. Sádecká, J. Polonský, Eur. Food Res. Technol., 2001, 212, 511-517.

[107] C. Thompson, V.C. Trenerry, Food Chem., 1995, 53, 43-50.

[108] S. Buskov, P. Moller, H. Sorensen, J.C. Sorensen, S. Sorensen, J. Chromatogr. A, 1998, 802, 233-241).

[109] M.C. Boyce, E.E. Spickett, J. Agric. Food Chem., 1999, 47, 1970-1975. 
[110] K. Fukushi, S. Takeda, S. Wakida, M. Yamame, K. Higashi, K. Hiiro, J. Chromatogr. A, 1997, 772, 313-320.

[111] O.K. Choi, J.S. Jo, J. Chromatogr. A, 1997, 781, 435-443.

[112] P.F. Cancalon, J. AOAC Int., 1999, 82, 95-106

[113] I. Valásková, E. Havránek, J. Chromatogr. A, 1999, 836, 201-208.

[114] S. Fanali, P. Catarcini, M.G. Quaglia, E. Camera, M. Rinaldi, M. Picardo, J. Pharm. Biomed. Anal., 2002, 29, 973-979.

[115] S.L. Adibi, K.A. Rennick, J. Chromatogr. A, 2001, 379-386.

[116] C. Feldl, P. Moler, J. Otte, H. Sorensen, Anal. Biochem., 1994, 217, 62-69.

[117] G.D. Lee, J.H. Kwon, Int. J. Food Sci. Tech., 1998, 33, 375-383.

[118] F.J. Morales, Food Chem., 2002, 76, 363-369.

[119] R.C. Borrelli, V. Fogliano, S.M. Monti, J.M. Ames, Eur. Food Res. Technol., 2002, 215, 210-215.

[120] W.K. Jung, K.S. Nam, F. Sahidi, S.K. Kim, J. Am. Oil Chem. Soc., 2001, 78, 651656.

[121] C. Romay, J. Armesto, D. Remirez, R. González, N. Ledon, I. García, Inflamm. Res., 1998, 47, 36-41.

[122] V.B. Bhat, K.M. Madyastha, Biochem. Biophys. Res. Commun., 2000, 275, 20-25.

[123] P.J. Viskari, C.L. Colyer, Anal Biochem., 2003, 319, 263-271.

[124] C. Simó, M. Herrero, C. Neusüß, M. Pelzing, E. Kenndler, C. Barbas, E. Ibáñez, A. Cifuentes, submitted for publication.

[125] M. Herrero, E. Ibáñez, F.J. Señoráns, A. Cifuentes, J. Chromatogr. A, 2004, 1047, 195-203. 


\section{FIGURE LEGENDS.}

Figure 1. General structure (C6-C3-C6) of flavonoids and chemical structure of flavonols, flavanols, isoflavonoids, anthocyanidins and flavanones.

Figure 2. CE electropherograms of: A) a standard mixture and B) a green tea extract sample. Buffer: $20 \mathrm{mM} \mathrm{KH}{ }_{2} \mathrm{PO}_{4}: 50 \mathrm{mM}$ sodium tetraborate:200 mM SDS 3:1:2 at pH 7.0. Capillary length $47 \mathrm{~cm}$ (effective length $40 \mathrm{~cm}$ ). Voltage, $30 \mathrm{kV}$. UV detection at 200 nm. Peak identification: GC, (-)-gallocatechin; EGC, (-)-epigallocatechin; C, (+)catechin, EGCG, (-)-epigallocatechin-3-gallate; EC, (-)-epicatechin; GCG, (-)gallocatechin gallate; ECG, (-)-epicatechin gallate; GA, gallic acid; Ac, acetone (EOF marker). From reference [27] with permission

Figure 3. Electropherogram of a mixture of nine flavonoids and caffeic acid. Buffer 35 $\mathrm{mM}$ borax $\mathrm{pH}$ 8.9. Field strength $240 \mathrm{~V} / \mathrm{cm}$. Capillary length, $70 \mathrm{~cm}$ (effective length, $45 \mathrm{~cm}$ ) and $75 \mu \mathrm{m}$ i.d.. From reference [52] with permission.

Figure 4. CE-MS base peak electropherogram and MS spectra of the main peaks detected in a rosemary extract obtained using subcritical water at $100^{\circ} \mathrm{C}$. CE-MS conditions: $50 \mu \mathrm{m}$ i.d. fused silica capillary, $87 \mathrm{~cm}$ total length. BGE: $40 \mathrm{mM}$ ammonium acetate, adjusted at pH 9.0 with ammonium hydroxide. Voltage: $20 \mathrm{kV}$. Injections: $10 \mathrm{~s}$ at $0.5 \mathrm{psi}$ (3448 Pa). Sheath liquid: 2-propanol/water 60:40 (v/v) containing $0.1 \%(\mathrm{v} / \mathrm{v})$ triethylamine, flow rate $0.24 \mathrm{~mL} / \mathrm{h}$. Drying gas $\left(\mathrm{N}_{2}\right): 7 \mathrm{~L} / \mathrm{min}$, $350{ }^{\circ} \mathrm{C}$. Nebulizing gas $\left(\mathrm{N}_{2}\right)$ : pressure 2 psi. MS analyses were carried out using negative polarity. Compound stability: $50 \%$. MS scan 200-500 m/z (target mass $=350$ $\mathrm{m} / \mathrm{z}$ ). Sample: rosemary extract, $10 \mathrm{mg} / \mathrm{ml}$ concentration. Peak assignment: 1, isoquercitrin; 2, not identified; 3, carnosic acid; 4, rosmarinic acid; 5, homoplantagenin; 6, gallocatechin. From reference [92].

Figure 5. Electropherograms of the CEC separation of tocopherols showing A) limit of detection corresponding to an injection of $10 \mu \mathrm{g} / \mathrm{ml}$ for each compounds, and B) limit of quantification, corresponding to an injection of $25 \mu \mathrm{g} / \mathrm{ml}$ for each compound. Conditions: Capillary with $100 \mu \mathrm{m}$ i.d. packed with $\mathrm{C}_{18}$. Mobile phase, acetonitrile- 
methanol (70:30 v/v) and $0.01 \% \mathrm{w} / \mathrm{v}$ ammonium acetate; Voltage, $30 \mathrm{kV}$. Peak identification: 1 , thiourea; 2, BHT; 3, $\delta$-tocopherol; 4, $\gamma$-tocopherol; 5. $\alpha$-tocopherol. From reference [114] with permission. 
Table 1. Separation of some representative flavonoids using different capillary electromigration methods.

\begin{tabular}{|c|c|c|c|c|c|}
\hline Flavonoid & Sample & CE Mode & Separation and detection parameters & Observations & Reference \\
\hline IsoF $^{\text {a) }}$ (daidzein, genistein) & Soy products & CZE & $\begin{array}{l}100 \mathrm{mM} \text { Borate buffer ( } \mathrm{pH} 11.0 \text { ) } \\
\text { Electrochemical detection (working electrode: }+0.70 \mathrm{~V} \text { ) }\end{array}$ & $\begin{array}{l}\text { LOD }{ }^{\mathrm{C}} \text { both compounds: } 1 \times 10^{-7} \\
\mathrm{~g} / \mathrm{ml}\end{array}$ & [38] \\
\hline IsoF (puerarin, daidzein) & $\begin{array}{l}\text { Puerariae radix } \\
\text { (traditional Chinese } \\
\text { medicinal herb) }\end{array}$ & MEKC & $\begin{array}{l}25 \mathrm{mM} \text { borate buffer (pH 7.8) with } 10 \mathrm{mM} \text { SDS } \\
\text { Electrochemical detection (working electrode: }+900 \mathrm{mV} \text { ) }\end{array}$ & $\begin{array}{l}\text { LOD puerarin: } 6 \times 10^{-7} \mathrm{~mol} / \mathrm{l} \\
\text { LOD daidzein: } 1.1 \times 10^{-6} \mathrm{~mol} / \mathrm{l}\end{array}$ & [36] \\
\hline $\begin{array}{l}\text { IsoF (puerarin, daidzein, } \\
\text { rutin) }\end{array}$ & $\begin{array}{l}\text { Puerariae lobata } \\
\text { (traditional Chinese } \\
\text { medicinal herb) }\end{array}$ & CZE & $\begin{array}{l}50 \text { mM borate buffer (pH 9.0) } \\
\text { Electrochemical detection (working electrode: }+0.9 \mathrm{~V} \text { ) }\end{array}$ & $\begin{array}{l}\text { LOD puerarin: } 0.344 \times 10^{-6} \mathrm{~mol} / \mathrm{l} \\
\text { LOD daidzein: } 0.241 \times 10^{-6} \mathrm{~mol} / \mathrm{l} \\
\text { LOD rutin: } 0.511 \times 10^{-6} \mathrm{~mol} / \mathrm{l}\end{array}$ & [37] \\
\hline $\begin{array}{l}\text { IsoF (biochanin A, } \\
\text { isoformononetin, } \\
\text { formononetin, prunetin, } \\
\text { daidzein, genistein) }\end{array}$ & Standard mixture & CZE & $\begin{array}{l}200 \mathrm{mM} \text { boric acid buffer (pH 10.5) with } 1 \mathrm{M} \text { sodium } \\
\text { hydroxide } \\
\text { UV detection at } 220 \mathrm{~nm} \text { (scan from } 190 \text { to } 400 \mathrm{~nm} \text { ) }\end{array}$ & LOD for all compounds: $01 \mu \mathrm{g} / \mathrm{ml}$ & [41] \\
\hline $\begin{array}{l}\text { IsoF (daidzein, genistein, } \\
\text { daidzin, genistin) }\end{array}$ & Toasted Soy Flour & CZE & $\begin{array}{l}200 \mathrm{mM} \text { boric acid (pH 8.6) } \\
\text { DAD detector: } 260 \mathrm{~nm} \text { and spectra from } 200 \text { to } 400 \mathrm{~nm}\end{array}$ & & [39] \\
\hline $\begin{array}{l}\text { IsoF (luteone wihteone, } \\
\text { genistein, lupinalbin A) }\end{array}$ & $\begin{array}{l}\text { Standards from } \\
\text { lupin isoflavones }\end{array}$ & CZE & $\begin{array}{l}200 \mathrm{mM} \text { boric acid (pH 8.6) } \\
\text { DAD detector: } 270 \mathrm{~nm} \text { and spectra from } 200 \text { to } 400 \mathrm{~nm}\end{array}$ & & [39] \\
\hline $\begin{array}{l}\text { Epicatechin, catechin, rutin, } \\
\text { kaempferol, quercetin }\end{array}$ & $\begin{array}{l}\text { Hippophae } \\
\text { rhamnoides }\end{array}$ & CZE & $\begin{array}{l}50 \mathrm{mM} \text { borate buffer (pH 9.0) } \\
\text { Electrochemical detection (working electrode: }+950 \mathrm{mV} \text { ) }\end{array}$ & & [19] \\
\hline $\begin{array}{l}\text { Flavonols (kaempferol-3- } \\
\text { rutinoside, avicularin, rutin, } \\
\text { quercitrin, isoquercitrin, } \\
\text { quercetin, kaempferol) }\end{array}$ & Standards mixture & CZE & $\begin{array}{l}0.1 \mathrm{M} \text { boric acid ( } \mathrm{pH} \mathrm{9.6)} \\
\mathrm{UV} \text { detector at } 280 \mathrm{~nm}\end{array}$ & Standards concentration: $1 \mathrm{mg} / \mathrm{ml}$ & {$[51]$} \\
\hline $\begin{array}{l}\text { Apigenin, baicalein, } \\
\text { naringenin, luteolin, } \\
\text { hesperetin, galangin, } \\
\text { kaempferol, quercetin, } \\
\text { myricetine, caffeic acid }\end{array}$ & Standards mixture & CZE & $\begin{array}{l}35 \mathrm{mM} \text { borax buffer (pH 8.9) } \\
\text { UV detector at } 250 \mathrm{~nm}\end{array}$ & LODs between $0.03-0.210 \mu \mathrm{g} / \mathrm{ml}$ & [52] \\
\hline $\begin{array}{l}\text { Narirutin, eriocitrin, naringin, } \\
\text { hesperidin, neohesperidin }\end{array}$ & Standards mixture & CZE & $\begin{array}{l}20 \mathrm{mM} \text { tetraborate buffer (pH 7.0) with } 10 \% \text { methanol and } \\
7.5 \mathrm{mM} \mathrm{mg} / \mathrm{ml} \mathrm{SBE- \beta CD}\end{array}$ & $\begin{array}{l}\text { Separation of diasteromers of } \\
\text { flavanone-7-O-glycosides }\end{array}$ & [55] \\
\hline $\begin{array}{l}\text { Epicatechin, catechin, rutin, } \\
\text { apigenin, luteolin, quercetin }\end{array}$ & $\begin{array}{l}\text { Ginkgo biloba } \\
\text { leaves }\end{array}$ & & $\begin{array}{l}50 \mathrm{mM} \text { borate buffer (pH 9.0) } \\
\text { Electrochemical detection (working electrode: }+1.00 \mathrm{~V} \text { ) }\end{array}$ & $\begin{array}{l}\text { LODs from } 1.4 \times 10^{-7} \text { to } 5.0 \times 10^{-7} \\
\mathrm{~g} / \mathrm{ml}\end{array}$ & [56] \\
\hline Quercetin, rutin, myricetin & Wine & MEKC & $150 \mathrm{mM}$ boric acid (pH 8.5) with $50 \mathrm{mM}$ SDS & & [57] \\
\hline
\end{tabular}




\begin{tabular}{|c|c|c|c|c|c|}
\hline quercetrin, kaempferol & & & DAD detection & & \\
\hline $\begin{array}{l}\text { Rutin, ferulic acid, apigenin, } \\
\text { luteolin, quercetin, caffeic } \\
\text { acid }\end{array}$ & Propolis & CZE & $\begin{array}{l}50 \mathrm{mM} \text { borate buffer (pH 9.2) } \\
\mathrm{UV} \text { detection at } 262 \mathrm{~nm}\end{array}$ & LODs from $3.7 \times 10^{-7}$ to $1.8 \times 10^{-6}$ & [59] \\
\hline $\begin{array}{l}14 \text { flavanones, flavonols and } \\
\text { flavones }\end{array}$ & $\begin{array}{l}\text { Standards of honey } \\
\text { flavoniods }\end{array}$ & MEKC & $\begin{array}{l}200 \mathrm{mM} \text { boric acid ( } \mathrm{pH} 8.5) \text { with } 50 \mathrm{mM} \text { SDS } \\
\text { UV detection at } 340 \mathrm{~nm})\end{array}$ & & [61] \\
\hline $\begin{array}{l}\text { Vanillin, quercetin, } \\
\text { kaempferol, apigenin }\end{array}$ & Propolis & MEKC & $\begin{array}{l}100 \mathrm{mM} \text { borate buffer (pH 8.5) with } 50 \mathrm{mM} \text { SDS } \\
\text { DAD detector: } 215 \text { and } 350 \mathrm{~nm} .\end{array}$ & & {$[62]$} \\
\hline Rutin & Buckwheat seeds & MEKC & $\begin{array}{l}50 \mathrm{mM} \text { borate buffer (pH 9.3) with } 100 \mathrm{mM} \text { SDS } \\
\text { UV detection at } 380 \mathrm{~nm}\end{array}$ & & [63] \\
\hline Anth $^{b}$. & Wine & CZE & $\begin{array}{l}50 \mathrm{mM} \text { borate buffer (pH 8.4) with } 15 \% \text { methanol } \\
\text { UV detection at } 599 \mathrm{~nm}\end{array}$ & $\begin{array}{l}\text { LOD malvidin-3-O-glucoside: } 1 \\
\mu \mathrm{g} / \mathrm{ml}\end{array}$ & {$[50]$} \\
\hline $\begin{array}{l}\text { Anth. (Cyanindin- and } \\
\text { pelargonidin-3-glucosides, } \\
\text { pelargonidin-3-rutinoside, } \\
\text { pelargonidin-3- } \\
\text { succinylglucoside) }\end{array}$ & Strawberry & CZE & $\begin{array}{l}150 \mathrm{mM} \text { borate buffer (pH 8.0) } \\
\text { DAD detection }\end{array}$ & & [45] \\
\hline $\begin{array}{l}\text { Anth (Cyanidin-3- } \\
\text { sambubioside-5-glucoside } \\
\text { cyanidin-3,5-diglucoside, } \\
\text { cyanidin-3-sambubioside, } \\
\text { cyanidin-3-glucoside) }\end{array}$ & Elderberry & CZE & $\begin{array}{l}150 \mathrm{mM} \text { borate buffer (pH 8.0) } \\
\text { DAD detection }\end{array}$ & & [45] \\
\hline $\begin{array}{l}\text { Anth. (Cyanidin-3-3glucoside } \\
\text { and 3-rutinoside, delphinidin- } \\
\text { 3-glucoside and 3-rutinoside ) }\end{array}$ & Blackcurrant & CZE & $\begin{array}{l}25 \mathrm{mM} \mathrm{NaH}_{2} \mathrm{PO}_{4} \text { and } 25 \mathrm{mM} \mathrm{Na}_{2} \mathrm{HPO}_{4} \text { apparent } \mathrm{pH} 1.5 \text { with } \\
30 \% \text { acetonitrile } \\
\text { UV detection at } 520 \mathrm{~nm}\end{array}$ & & [47] \\
\hline $\begin{array}{l}\text { Anth. (cyanidin-3-galactoside } \\
\text { and 3-glucoside and 3,5- } \\
\text { diglucoside, malvidin 3,5- } \\
\text { diglucoside) }\end{array}$ & Standards mixture & CZE & $\begin{array}{l}0.25 \mathrm{mM} \text { cetyltrimethylammoniumbromide in } 160 \mathrm{mM} \\
\mathrm{NaH}_{2} \mathrm{PO}_{4} / \mathrm{H}_{3} \mathrm{PO}_{4}(\mathrm{pH} \sim 2.1) \\
\text { UV detection at } 520 \mathrm{~nm}\end{array}$ & & [48] \\
\hline Anth. (peonidin, cyanidin) & Cranberries & CZE & $\begin{array}{l}150 \mathrm{mM} \text { phosphoric acid, } 3 \mathrm{M} \text { urea, } 50 \mathrm{mM} \beta-\mathrm{CD}(\mathrm{pH} 2.11) \\
\mathrm{UV} \text { detection at } 525 \mathrm{~nm}\end{array}$ & & [49] \\
\hline $\begin{array}{l}\text { Epicatechin, catechin, } \\
\text { epigallocatechin, p-coumaric } \\
\text { acid, caffeic acid }\end{array}$ & Wine & CZE & $\begin{array}{l}0.1 \text { M borate buffer ( } \mathrm{pH} 9.5) \\
\text { UV detection at } 280 \mathrm{~nm}\end{array}$ & Different wine types tested & [72] \\
\hline $\begin{array}{l}\text { Epicatechin, catechin, p- } \\
\text { coumaric, caffeic, syringic }\end{array}$ & Wine & CZE & $\begin{array}{l}0.1 \text { M borate buffer ( } \mathrm{pH} 9.5) \\
\text { UV detection at } 280 \mathrm{~nm}\end{array}$ & & [73] \\
\hline
\end{tabular}




\begin{tabular}{|c|c|c|c|c|c|}
\hline and gallic acids & & & & & \\
\hline $\begin{array}{l}\text { Quercetin, catechin, gallic } \\
\text { acid }\end{array}$ & Wine & MEKC & $\begin{array}{l}6 \mathrm{mM} \text { borate and } 10 \mathrm{mM} \text { phosphate buffer ( } \mathrm{pH} 9.3 \text { ) with } 50 \\
\mathrm{mM} \text { sodium deoxycholate } \\
\text { UV detection at } 220 \mathrm{~nm}\end{array}$ & & [73] \\
\hline Epicatechin, catechin & Wine & CZE & $\begin{array}{l}100 \mathrm{mM} \text { borate buffer }(9.2) \\
\text { Electrochemical detection (working electrode }+0.85 \mathrm{~V} \text { ) }\end{array}$ & $\begin{array}{l}\text { LOD both compounds: } 5 \times 10^{-7} \\
\mathrm{~g} / \mathrm{ml}\end{array}$ & [78] \\
\hline
\end{tabular}

${ }^{\mathrm{a}}$ IsoF: Isoflavones; ${ }^{\mathrm{b}}$ Anth: Anthocyanins; ${ }^{\mathrm{c}} \mathrm{LOD}$ : Limit of detection. 
Table 2. Separation of catechins from tea using different capillary electromigration methods

\begin{tabular}{|c|c|c|c|c|c|c|c|}
\hline Type of tea & $\begin{array}{l}\text { Catechins } \\
\text { identified } \\
\end{array}$ & $\begin{array}{l}\mathrm{CE} \\
\text { mode } \\
\end{array}$ & Buffer & Detection & Other parameters & Other compounds detected & $\overline{\text { Reference }}$ \\
\hline Green & $\begin{array}{l}\text { EC, EGC, ECG, } \\
\text { EGCG, C }\end{array}$ & $\mathrm{CZE}$ & $20 \mathrm{mM}$ Borax pH 8.0 & UV $200 \mathrm{~nm}$ & $\begin{array}{l}\text { Capillary: } 50 \mu \mathrm{m} \text { ID. } \\
70 \mathrm{~cm} \text { d.l., } 30 \mathrm{kV} .\end{array}$ & Ascorbic acid & {$[21]$} \\
\hline $\begin{array}{l}\text { Green, } \\
\text { Black, } \\
\text { Oolong }\end{array}$ & $\begin{array}{l}\text { EC, EGC, ECG, } \\
\text { EGCG }\end{array}$ & MEKC & 80 mM Borate pH 8.450 mM SDS & $\begin{array}{r}\text { DAD } 270 \mathrm{~nm} \\
174 \mathrm{~nm}\end{array}$ & $\begin{array}{l}\text { Capillary: } 75 \mu \mathrm{m} \text { ID., } \\
70 \text { cm d.l., } 25 \mathrm{kV}\end{array}$ & Ascorbic acid & {$[22]$} \\
\hline Green & $\begin{array}{l}\text { EGC, C, EC, } \\
\text { EGCG, ECG }\end{array}$ & MEKC & $\begin{array}{lllll}50 \mathrm{mM} & \mathrm{NaH}_{2} \mathrm{PO}_{4}, \quad 50 & \mathrm{mM} & \text { sodium } \\
\text { tetraborate, } 20 & \mathrm{mM} & \mathrm{SDS}, & 10 \% \\
\text { acetonitrile } & & & & \end{array}$ & DAD $278 \mathrm{~nm}$ & $\begin{array}{l}\text { Capillary: } 50 \mu \mathrm{m} \text { ID., } \\
56 \mathrm{~cm} \text { d.l., } 30 \mathrm{kV}\end{array}$ & $\begin{array}{l}\text { Various flavonoids and their } \\
\text { gycosides }\end{array}$ & [23] \\
\hline Darjeeling & EC, EGCG, ECG & & & & & Diverse flavonoids & \\
\hline Black & EGCG, ECG & & & & & Diverse flavonoids & \\
\hline $\begin{array}{l}\text { Green } \\
\text { Black } \\
\text { Darjeeling } \\
\end{array}$ & $\begin{array}{l}\text { ECG, EC, } \\
\text { EGCG, EGC }\end{array}$ & MEKC & $\begin{array}{l}100 \mathrm{mM} \text { SDS in } 90 \% 20 \mathrm{mM} \text { phosphate } \\
\text { (pH 2.5), } 10 \% \text { methanol }\end{array}$ & UV $195 \mathrm{~nm}$ & $\begin{array}{l}\text { Capillary: } 50 \mu \mathrm{m} \mathrm{ID,} \\
45 \text { cm d.l., }\end{array}$ & & {$[24]$} \\
\hline Green & $\begin{array}{l}\text { EGCG, EGC, } \\
\text { ECG, EC, C }\end{array}$ & CZE & $0.15 \mathrm{M} \mathrm{H}_{3} \mathrm{BO}_{3} \mathrm{pH} 8.5$ & UV $210 \mathrm{~nm}$ & $\begin{array}{l}\text { Capillary: } 75 \mu \mathrm{m} \text { ID, } \\
50 \mathrm{~cm} \text { d.l., } 20 \mathrm{kV}\end{array}$ & Quercetin, gallic acid, caffeic acid & {$[25]$} \\
\hline Green & $\begin{array}{ll}\text { GC, C, } & \text { EGC, } \\
\text { EGCG, } & \text { CGG, } \\
\text { ECG, EC } & \\
\end{array}$ & MEKC & $\begin{array}{l}20 \mathrm{mM} \quad \mathrm{KH}_{2} \mathrm{PO}_{4} / \quad 50 \mathrm{mM} \quad \text { sodium } \\
\text { tetraborate/ } \\
200 \mathrm{mM} \text { SDS 3:1:2. pH } 7.0\end{array}$ & UV $200 \mathrm{~nm}$ & $\begin{array}{l}\text { Capillary: } 50 \mu \mathrm{m} \text { ID, } \\
40 \mathrm{~cm} \text { d.l., } 30 \mathrm{kV}\end{array}$ & & {$[27]$} \\
\hline Fresh leaf & $\begin{array}{l}\text { C, GC, EC, } \\
\text { EGC, ECG, } \\
\text { EGCG }\end{array}$ & MEKC & $\begin{array}{l}25 \text { mM phosphate } \mathrm{pH} 7.0100 \mathrm{mM} \text { SDS, } \\
6 \% \text { methanol }\end{array}$ & UV $200 \mathrm{~nm}$ & $\begin{array}{l}\text { Capillary: } 50 \mu \mathrm{m} \text { ID, } \\
51 \mathrm{~cm} \text { d.l., } 14 \mathrm{kV}\end{array}$ & & [28] \\
\hline $\begin{array}{l}\text { Fresh leaf } \\
\text { Black }\end{array}$ & $\begin{array}{l}\text { EC, C, EGC, } \\
\text { ECG, EGCG }\end{array}$ & MEKC & $\begin{array}{l}25 \mathrm{mM} \text { phosphate } \mathrm{pH} 7.0100 \mathrm{mM} \text { SDS, } \\
6 \% \text { methanol }\end{array}$ & UV $200 \mathrm{~nm}$ & $\begin{array}{l}\text { Capillary: } 50 \mu \mathrm{m} \text { ID, } \\
50 \text { cm d.l., } 14 \mathrm{kV}\end{array}$ & Gallic acid, ascorbic acid & {$[20]$} \\
\hline $\begin{array}{l}\text { Green } \\
\text { Black }\end{array}$ & $\begin{array}{l}\text { C, CG, EC, } \\
\text { ECG, EGC, } \\
\text { EGCG }\end{array}$ & CZE & $\begin{array}{l}40 \% 500 \mathrm{mM} \text { boric acid, } 10 \% \text { of } 100 \\
\mathrm{mM} \mathrm{KH}_{2} \mathrm{PO}_{4}, 22.5 \% \text { of } 20 \mathrm{mM} \beta-\mathrm{CD} \\
\text { and } 27.5 \% \text { of ACN }\end{array}$ & DAD 205 nm & $\begin{array}{l}\text { Capillary: } 50 \mu \mathrm{m} \text { ID, } \\
40 \mathrm{~cm} \text { d.l., } 25 \mathrm{kV}\end{array}$ & Quercetin, gallic acid, caffeic acid & [31] \\
\hline
\end{tabular}

EC: (-)-epicatechin, EGC: (-)-epigallocatechin, ECG: (-)-epicatechin gallate, EGCG: (-)-epigallocatechin gallate, C: (+)-catechin, GC: (-)gallocatechin, GCG: (-)-gallocatechin gallate. 


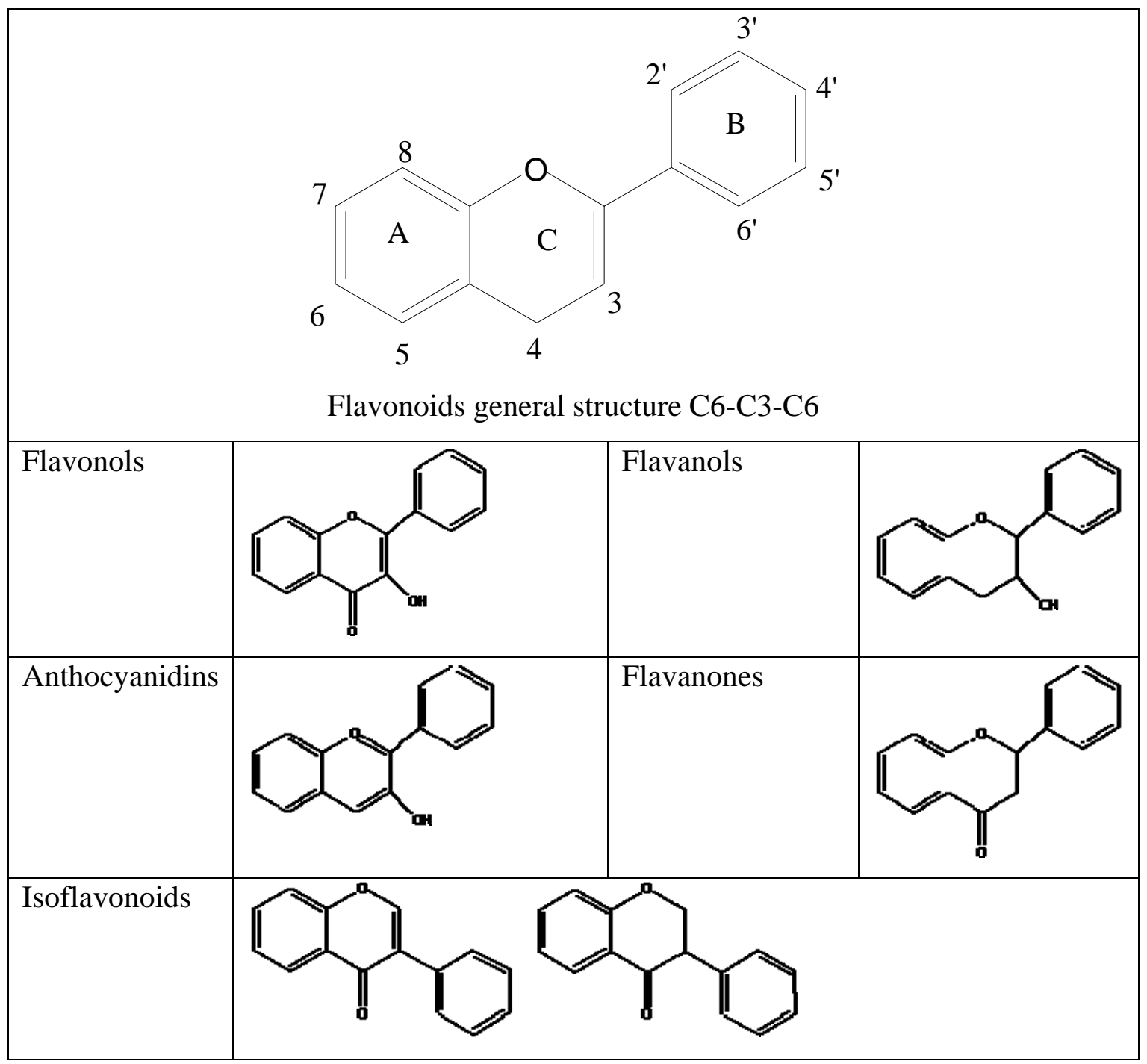

Figure 1. 

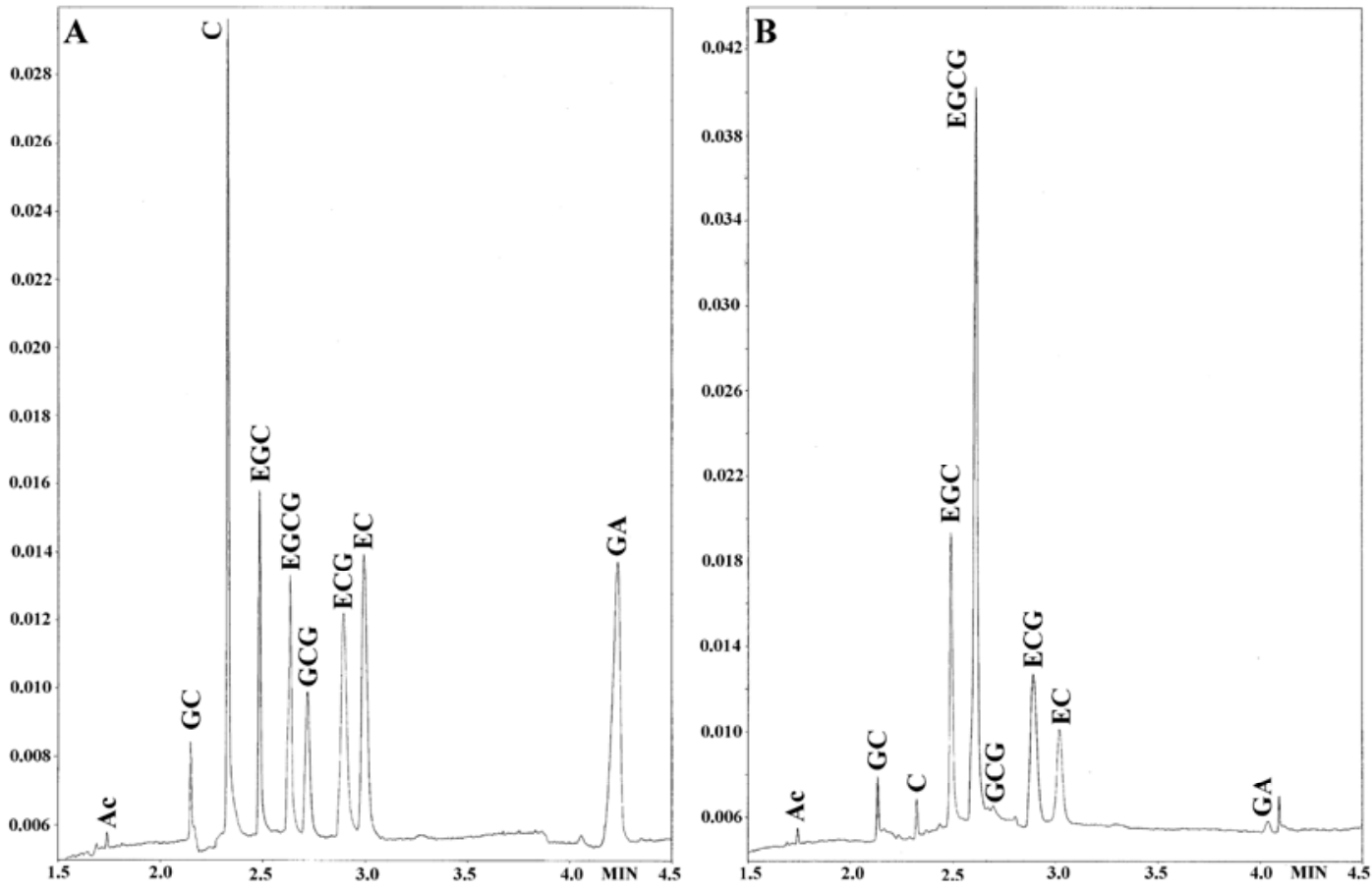

Figure 2. 


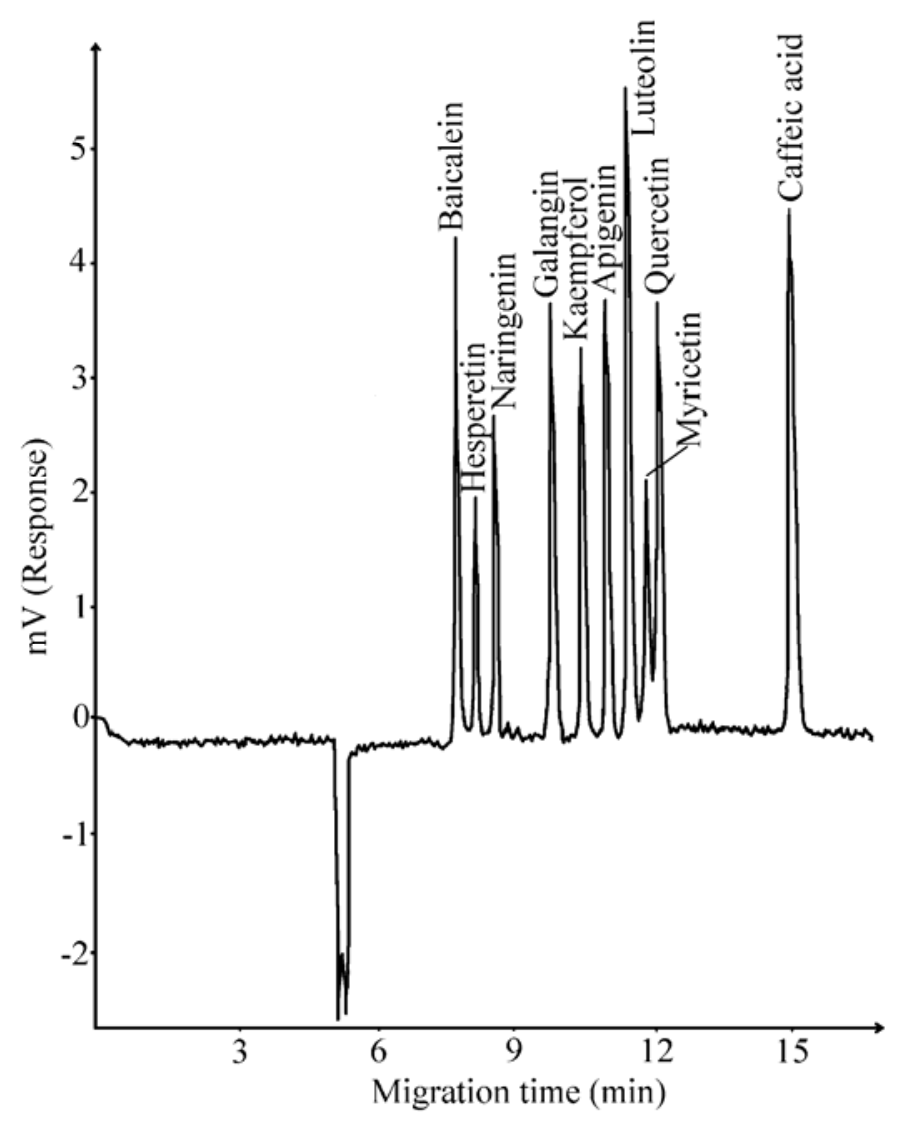

Figure3. 

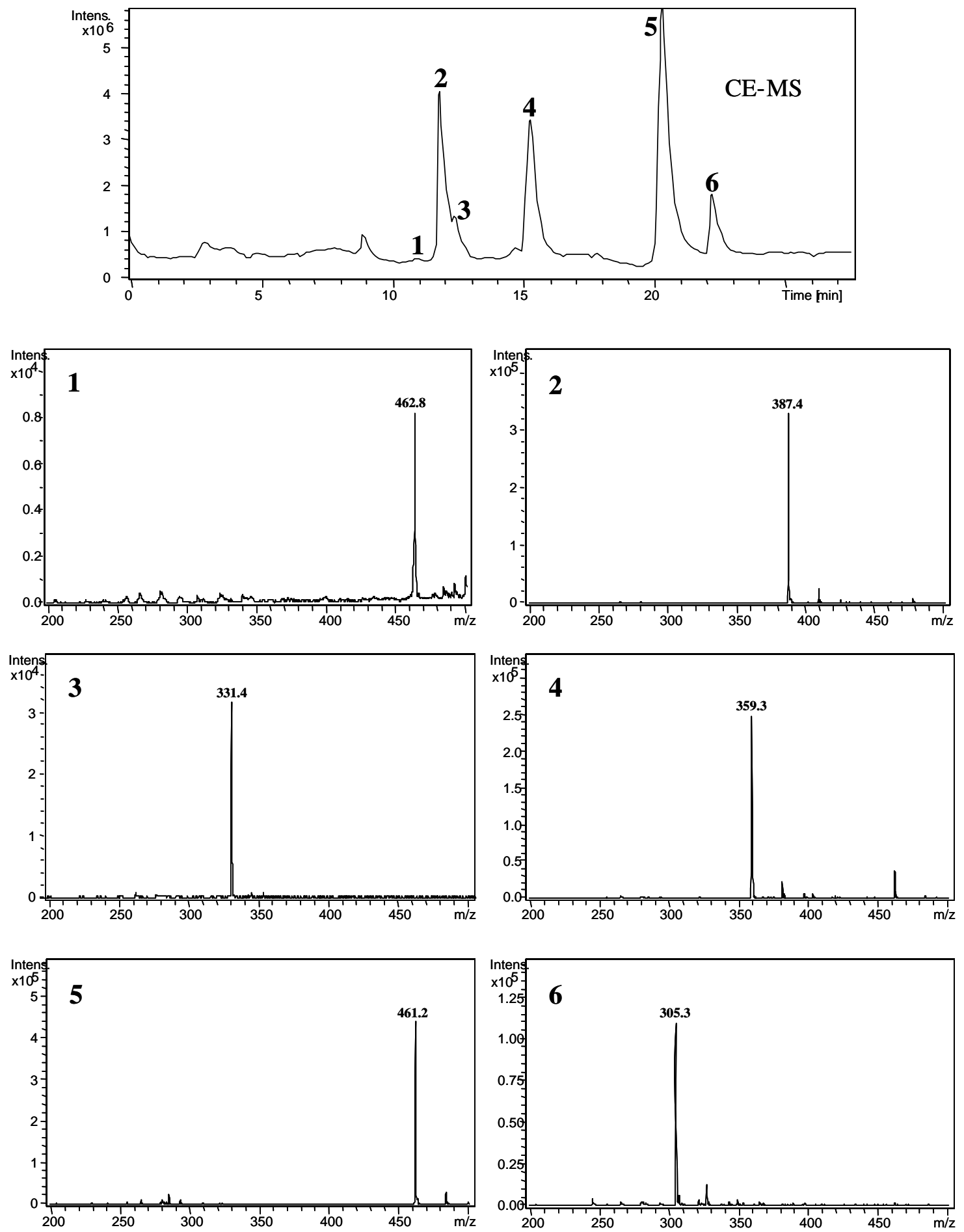

Figure 4. 


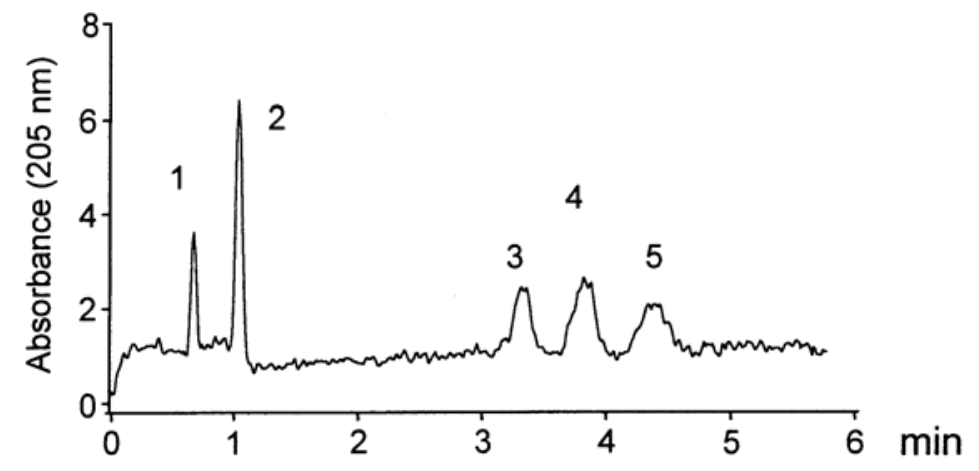

b

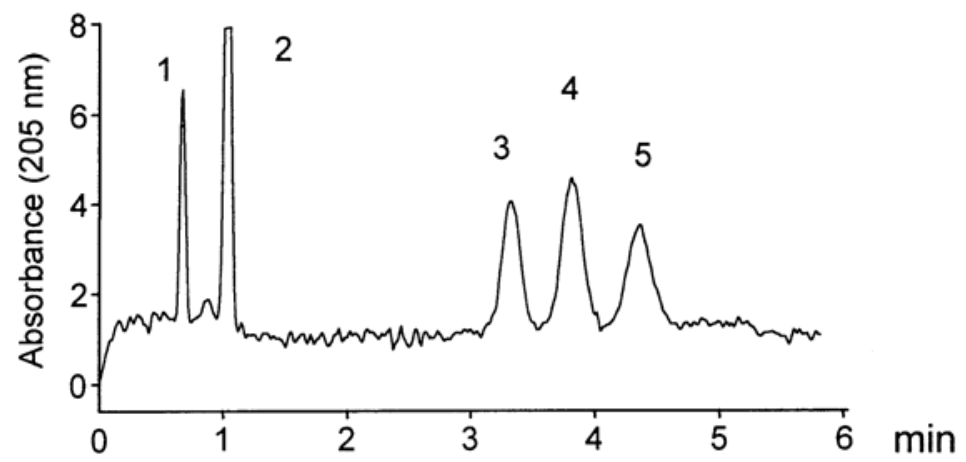

Figure 5. 